\title{
OBEZITATEA ŞI PATOLOGIA RESPIRATORIE ASOCIATĂ SOMNULUI LA COPIL
}

\author{
Dr. Oana Iaru' ${ }^{1}$, Dr. Mihaela Oros ${ }^{2}$, Prof. Dr. D. Orăşeanu ${ }^{1}$ \\ ${ }^{1}$ Clinica Pediatrie, Spitalul Clinic de Urgență pentru Copii ,, Grigore Alexandrescu“, \\ Bucureşti \\ ${ }^{2}$ Clinica ,Medicover", Bucureşti
}

\begin{abstract}
REZUMAT
Obezitatea reprezintă o problemă de sănătate publică, cu o creştere impresionantă a prevalenței în ultimele decenii, populația pediatrică înscriindu-se în aceste caracteristici. Printre complicațiile multiorganice asociate obezități se numără şi patologia respiratorie legată de somn. Asocierea apnee obstructivă de somn - obezitate este suspectată anamnestic la un copil care sforăie, prezintă fragmentarea somnului şi pauze respiratorii, patologia respiratorie fiind obiectivată prin polisomnografie. Apneea obstructivă de somn prezintă numeroase complicații (multe dintre ele augmentate prin asocierea obezității) - cardiace, metabolice, neurocognitive, ce afectează calitatea vieții. Tratamentul constă în scădere în greutate, adenoamigdalectomie şi folosirea ventilației de tip CPAP.

Cuvinte cheie: obezitate, apnee obstructivă de somn
\end{abstract}

Mențiune: Această lucrare este efectuată în cadrul Programului Operațional Sectorial pentru Dezvoltarea Resurselor Umane (POSDRU), finanțat din Fondul Social European şi Guvernul României prin contractul nr. POSDRU/ 159/1.5/S/137390.

\section{OBEZITATEA LA COPIL}

Obezitatea reprezintă în ultimele decenii o adevărată problemă de sănătate publică prin creşterea prevalenței sale atât în rândul copiilor, cât şi al adulților şi prin consecințele multiorganice pe termen lung (cardiovasculare, metabolice, renale, neurologice, ortopedice, dar şi psiho-sociale). Conform unor date publicate de National Health and Nutrition Examination Survey - evaluare comparativă pentru anii 1976-1980 şi 2003-2006, prevalența obezităţii a crescut semnificativ (pentru grupa de vârstă 2-5 ani de la 5\% la $12,4 \%$, pentru grupa 6-11 ani de la $6,5 \%$ la $17 \%$, iar pentru $12-19$ ani s-a înregistrat creştere procentuală de la $5 \%$ la $17,6 \%$ ). (1)

Pentru definirea obezității este nevoie de graficele CDC pentru indicele de masă corporală: un indice de masă corporală aflat deasupra percentilei 85 pentru vârstă şi sex încadrează copilul ca fiind supraponderal, iar un indice de masă corporală peste percentila 95 semnifică obezitate.
Obezitatea poate fi privită ca o afectare multisistemică, având consecințe asupra întregului organism. Printre complicațiile asociate obezitații un rol central îl ocupă afectarea hepatică definită prin două entități patologice: NAFLD (nonalcoholic fatty liver disease) şi NASH (nonalcoholic steatohepatitis). Afectarea hepatică se traduce din punct de vedere fiziopatologic prin consecințe locale hepatice (steatoză, distrucție hepatocitară, afectarea funcției hepatice, inflamație), dar mai ales prin efecte sistemice: creşterea riscului cardiovascular, rezistență la insulină şi diabet zaharat de tip II, dislipidemie. (2)

Sindromul metabolic este o entitate clinică de sine stătătoare, definită clar la copiii cu vârstă peste 6 ani (nu există date suficiente pentru definire la copiii mai mici de 6 ani) prin următoarele criterii (IDF 2007): obezitate de tip central - circumferința taliei mai mare de $94 \mathrm{~cm}$ la băieți şi $80 \mathrm{~cm}$ la fete; trigliceride mai mari de $150 \mathrm{mg} / \mathrm{dl}$; HDL- colesterol 
mai mic de $40 \mathrm{mg} / \mathrm{dl}$ la băieți şi $50 \mathrm{mg} / \mathrm{dl}$ la fete sau tratament specific pentru dislipidemie; tensiune arterială peste $130 / 85 \mathrm{~mm} \mathrm{Hg}$ sau tratament pentru hipertensiune arterială diagnosticată anterior, glicemie a jeun mai mare de $100 \mathrm{mg} / \mathrm{dl}$ sau diabet zaharat de tip II diagnosticat anterior. (3)

Printre celelalte complicații asociate obezității se numără: maturare osoasă accelerată, patologie ortopedică, hiperandrogenism, glomeruloscleroză focală, probleme emoționale şi psiho-sociale. (4)

\section{APNEEA OBSTRUCTIVĂ DE SOMN}

În ceea ce priveşte patologia respiratorie asociată obezității, caracteristic este sindromul apneei obstructive în timpul somnului. Acest sindrom a fost descris la copii în 1970 şi are următoarea definiție: tulburare de respirație caracterizată prin episoade recurente parțiale sau complete de obstrucție la nivelul căilor respiratorii superioare, asociată uzual cu hipoxemie intermitentă şi fragmentarea somnului. (5)

Prevalenţa apneei obstructive se încadrează între 1 şi 5,7\%, obezitatea fiind factorul de risc cel mai important pentru această patologie (6), incidența de vârf înregistrându-se la grupa de vârstă 5-10 ani (11). În majoritatea studiilor, prevalența este egală pe sexe, există însă şi studii în care proporția băieților este mai mare. (7)

În ceea ce priveşte asocierea între apneea obstructivă şi obezitate, datele din literatură arată astfel: aproximativ $10 \%$ dintre copiii diagnosticaţi cu apnee obstructivă de somn sunt obezi (8) şi între 46 şi 59\% dintre copiii obezi ce fac polisomnografie prezintă patologie respiratorie de somn. $(9,10)$; de asemenea, studiile arată că obezitatea crește riscul de apnee asociată somnului de aproximativ 4 ori.

Din punct de vedere fiziopatologic apneea obstructivă asociată somnului are 4 fenotipuri: primul dintre ele este caracterizat de asocierea cu hipertrofia adeno-amigdaliană, afectează $2 \%$ dintre copiii între 2 şi 8 ani şi poate determina deficite neurocognitive şi cardiovasculare severe dacă rămâne netratat; cel de-al doilea fenotip este asociat cu malformații cranio-faciale, este un fenotip sindromic (Down, Pierre-Robin), afectarea respiratorie apare curând după naştere; cel de-al treilea fenotip este caracterizat de asocierea cu afecțiuni neuromusculare primare (distrofie musculară Duchenne, amiotrofie spinală) - poate asocia şi alte forme de tulburare respiratorie (hipoxemie, hipoventilație fără obstrucție francă); cel de-al patrulea fenotip este întâlnit la copiii obezi.

\section{APNEEA OBSTRUCTIVĂ DE SOMN ŞI OBEZITATEA}

Din punct de vedere fiziopatologic, asocierea acestor două entități poate fi explicată prin interacțiunea dintre factori anatomici (hipertrofia adenoamigdaliană) şi factori funcționali (colabare crescută căi respiratorii superioare, afectare perete toracic, răspuns ventilator scăzut la hipoxie şi hipercapnie). Hipertrofia adenoidiană (prezentă la $45 \%$ dintre copiii obezi cu patologie respiratorie asociată somnului) poate fi influenţată şi de inflamația locală sau sistemică, factori hormonali, prezența altor structuri locale - țesuturi moi - ce pot modifica calibrul căilor respiratorii. Din alt punct de vedere, obezitatea determină scăderea complianței pulmonare şi a capacității reziduale funcționale, consecințele fiind următoarele: hipoventilație, creşterea travaliului respirator, modificări ale raportului ventilație/perfuzie. De asemenea, copiii obezi prezintă răspuns ventilator alterat la hipoxie şi hipercapnie.

\section{CLINICA APNEEI OBSTRUCTIVE DE SOMN}

La copiii mici simptomele caracteristice sunt: creşterea efortului respirator în timpul somnului, sforăit, pauze respiratorii/apnee, respirație orală. Aceştia prezintă poziții anormale în timpul somnului (pronație cu extensia gâtului), iar părinții se pot plânge de «probleme de somn», respectiv somn neliniştit, mişcări frecvente, treziri dese. Copiii pot asocia enurezis nocturn, iar în timpul zilei prezintă fatigabilitate, iritabilitate, dificultăți de trezire.

La copiii mai mari, primul semn care atrage atenția este reprezentat de sforăit; prezintă şi ei dificultăți de respirație, somnolență diurnă, tulburări de atenție şi concentrare, pot asocia cefalee matinală ocazional.

\section{DIAGNOSTICUL PARACLINIC AL APNEEI OBSTRUCTIVE DE SOMN}

Cea mai simplă metodă de diagnostic (dar cu specificitate scăzută) este anamnestică, prin aplicarea unor chestionare care să cuantifice simptomatologia respiratorie nocturnă. În acest mod sunt identificate unele aspecte caracteristice (majoritatea părinților pot răspunde la întrebările legate de sforăit), însă pauzele respiratorii nu pot fi sesizate întotdeauna de părinți deoarece apar mai ales în timpul somnului REM (noaptea târziu). Chestionarele pediatrice pentru somn sunt în număr scăzut, majoritatea fiind adaptări ale celor pentru adulți; 
acestea au întrebări care să obiectiveze simptomele respiratorii în timpul somnului, calitatea somnului, patternul de comportament caracteristic somnului şi hipersomnolența diurnă.

O altă metodă de diagnostic este reprezentată de pulsoximetria nocturnă la domiciliu. Aceasta este pozitivă cînd graficul arată desaturări pe una sau mai multe perioade de 10-30 minute peste noapte. Pulsoximetria pozitivă poate fi specifică pentru apneea obstructivă de somn, însă cea negativă nu exclude această simptomatologie.

Se poate folosi şi poligrafia respiratorie (înregistrare nocturnă a parametrilor respiratori). Această tehnică nu permite însă monitorizarea parametrilor neurologici şi a stadiilor somnului.

Standardul de aur pentru diagnosticul paraclinic al apneei obstructive de somn este însă polisomnografia. Prin această tehnică sunt monitorizați parametrii neurologici (EEG, EMG) şi respiratori (presiune nazală, pulsoximetrie, monitorizare presiune CO2). Apneea obstructivă este mai lungă de două cicluri respiratorii şi apare predominant în somnul REM. Prin consens se defineşte apneea obstructivă de somn prin prezența unui index de apnee mai mare ca 1 şi a AHI (apnea-hypopnea index) mai mare de 1,5 .

Trebuie menționat că la copiii mai mici există un pattern diferit al modificărilor respiratorii în timpul somnului, aceştia prezentând obstrucție importantă a căilor respiratorii superioare în timpul somnului, dar fără apnee, doar cu hipercapnie şi/ sau hipoxemie; această manifestare poartă numele de hipoventilație obstructivă. (11)

\section{ALGORITM DE DIAGNOSTIC LA COPIII OBEZI CU POSIBILĂ APNEE OBSTRUCTIVĂ DE SOMN}

Există două direcții de abordare pentru screening şi diagnostic la copiii cu aceste patologii: în primul rând ar trebui încadrați corect copiii cu supraponderalitate şi obezitate şi pentru aceştia să se facă anamneza patologiei respiratorii asociate somnului (pot fi folosite chestionarele validate în populația adultă, modificate pentru copii - Berlin questionnaire, Epworth sleepiness scale), urmând ca apoi să se efectueze alte investigatii diagnostice acolo unde datele sunt sugestive; iar cea de-a doua abordare ar consta în efectuarea corectă a screeningului pentru descoperirea copiilor obezi şi neobezi care prezintă probleme respiratorii de somn (sforăit, apnee, hipopnee, fragmentarea somnului). (5)

\section{COMPLICATII OBEZITATE - APNEE OBSTRUCTIVĂ DE SOMN}

\section{Cardiovasculare}

Ca şi efecte pe termen lung ale acestei asocieri putem vorbi de: hipertensiune pulmonară ce poate ajunge până la cord pulmonar, determinată de hipoxemia severă nocturnă şi hipercapnia şi acidoza ce apar în timpul hipoventilației/apneei; mai pot apărea, de asemenea, hipertensiune arterială sistemică, hipertrofie ventriculară stângă (remodelare ventriculară stângă). (12)

La adulți, asocierea obezitate - apnee obstructivă de somn este corelată clar cu riscul cardiovascular (respectiv boală coronariană, insuficiență cardiacă acută, accident vascular cerebral), aşa cum se arată într-un studiu făcut pe 6.400 de adulți obezi. (13) La copii nu există atât de multe studii, însă datele din literatură arată, de asemenea, creşterea riscului pentru hipertensiune arterială sistemică şi pierderea modulației circadiene a valorilor tensiunii arteriale, respectiv lipsa scăderii fiziologice nocturne a acesteia (nocturnal dipping). (14)

Mecanismele fiziopatologice care duc la apariția acestor efecte cardiovasculare sunt următoarele: hipoxia intermitentă şi fragmentarea somnului determină activarea sistemului nervos simpatic şi creşterea stresului oxidativ, prin urmare cresc factorii activatori vasculari proinflamatori determinând disfuncție endotelială şi activare plachetară.

\section{Metabolice}

Apneea obstructivă este mediator pentru rezistența la insulină, dislipidemie, inflamație, tromboză prin următoarele mecanisme: descărcare simpatică importantă, hipoxemie intermitentă, inflamație, tromboză. Morbiditatea asociată acestor manifestări este mai mare la copii comparativ cu adulții datorită debutului precoce.

Există o asociere independentă a tulburărilor respiratorii de somn cu rezistența la insulină, asociere ce nu ține cont de prezența obezității. (15)

Tratamentul apneei obstructive (adeno-amigdalectomie, CPAP) determină scăderea glicemiei şi a rezistenței la insulină şi o funcționare mai bună a celulelor beta pancreatice. (16)

Efectele metabolice ale asocierii patologice obezitate - apnee obstructivă de somn sunt puse sub rezerva unei dificultăți de interpretare datorită faptului că obezitatea poate determina prin ea însăşi, fără alte asocieri, aceste consecințe. 


\section{Neurocognitive}

Printre modificările neurocognitive menţionate în literatura de specialitate se numără: modificările comportamentale, dificultățile de învățare, deficitul de atenție, hiperactivitatea, agresivitatea, scăderea performanțelor şcolare.

Scăderea performanțelor şcolare este determinată de afectarea memoriei şi atenției, deteriorarea abilităţilor de învățare; coeficientul de inteligență al acestor copii fiind scăzut comparativ cu al copiilor de aceeaşi vârstă ce nu asociază această patologie.

Din punct de vedere fiziopatologic modificarile neurocognitive pot fi explicate prin următorul mecanism: episoadele repetate de hipoxemie nocturnă secundare episoadelor de apnee/hipopnee determină în timp afectare ischemică cerebrală, de asemenea fragmentarea somnului şi calitatea scăzută a acestuia determină hipersomnolență diurnă, contribuind suplimentar la deficitul de atenţie şi concentrare.

Copiii obezi cu apnee obstructivă prezintă în proporție mare deficite de memorie, vocabular sărac, tulburări de limbaj, dificultăți de învățare comparativ cu copiii obezi ce nu asociază patologie respiratorie. (17)

În cadrul patologiei psihiatrice asociate, o atenție deosebită trebuie acordată ADHD-ului; tulburările respiratorii de somn fiind înalt predictive pentru diagnostic de hiperactivitate pe termen lung. (18)

Deficitele cognitive şi neuropsihice la copiii cu patologie respiratorie asociată somnului se îmbunătățesc după tratamentul acestei afecțiuni (se observă ameliorare pentru hiperactivitate, impulsivitate, deficit de atenție, tulburări de comportament); de asemenea, se poate cuantifica creşterea calităţii vieții acestor copii în urma tratamentului.

Este important de ştiut însă că nu toate deficiențele neuropsihice se ameliorează odată cu tratamentul, există studii care atestă faptul că tulburările de limbaj şi coeficientul de inteligență nu se îmbunătățesc semnificativ după tratament. (11)

\section{TRATAMENT}

Pentru populația de copii obezi ce asociază patologie respiratorie de somn, prima măsură terapeutică este scăderea în greutate (etapă esențială ce poate rezolva de multe ori afectarea respiratorie sau se poate asocia celorlalte măsuri terapeutice).
Adenoamigdalectomia este tratamentul de elecție pentru apneea obstructivă asociată somnului la copil. Ca şi complicaţie a acestei metode terapeutice este citată în literatura de specialitate (cu frecvență mai mare decât în populația generală) apariția laringospasmului. (19)

Studiile arată că în populația copiilor cu obezitate, procentul celor $\mathrm{cu}$ afectare respiratorie reziduală după adeno-amigdalectomie este mai mare decât în populația pediatrică fără obezitate (până la $70 \%$ comparativ cu $30 \%$ ). Adenoamigdalectomia determină îmbunătăţirea AHI şi a oxigenării la copiii obezi cu apnee obstructivă de somn, însă 50\% dintre aceştia continuă să aibă AHI (indice apnee/ hipopnee) mai mare decât 5. (5) În concluzie, putem vorbi de ameliorarea apneei obstructive de somn după adenoamigdalectomie şi la copiii obezi, însă cu un procent mai mare de boală reziduală dacă la această metodă terapeutică nu se asociază şi un program de scădere în greutate.

A doua linie de tratament este reprezentată de folosirea ventilaţiei de tip CPAP (continuous positive airway pressure). Folosirea CPAP este eficientă în tratamentul apneei obstructive asociate somnului, însă aderența la tratament este o problemă semnificativă, acesta fiind motivul pentru care nu este recomandată ca tratament de primă linie.

Mai poate fi folosită ca mijloc de tratament adjuvant terapia pozițională - tricouri, perne, centuri care asigură o anumită poziţie în timpul somnului care să eficientizeze circulația fluxului de aer.

Se mai poate efectua uvulopalatofaringoplastie - aceasta presupune micşorarea pilierilor faringieni laterali şi mărirea calibrului căii aeriene prin îndepărtarea uvulei şi a palatului posterior. Se foloseşte mai ales la copiii mai mari care nu tolerează ventilația de tip CPAP, dar este grefată de complicații ca: insuficiență velo-palatină, stenoză, disfagie.

O discuție aparte se poartă în ceea ce priveşte copiii cu obezitate morbidă la care mijloacele de tratament menționate pentru tulburările respiratorii de somn nu sunt eficiente. La aceşti copii se ia în discuție chirurgia bariatrică - atunci când celelalte metode de scădere în greutate au dat greş. Conform studiilor, chirurgia bariatrică determină scăderea semnificativă a simptomatologiei respiratorii asociată somnului, însă nu total, cu scăderea timpului de folosire a CPAP. (5) 